\title{
Special Issue Introduction:
}

\section{"...to tun de words roun an roun..."}

\author{
(From Judith Hamilton's: 'Poem Teacha', 1987, p. 99) \\ Cecille DePass
}

How can I express the feelings that aptly describe that 'one a we' has been invited to present a Keynote lecture for the SSHRC Congress at the University of Ottawa? This prestigious, national academic conference, annually, showcases some of the very best thinking and research in the country. The conference was once called: "The Learneds Societies Conference", at a time when the boundaries between 'town and gown' were firmly delimited. This was the case, in the late 1980s, when I presented a summary of my dissertation research, at the Windsor conference in spring 1988.

Yet, since then, some things have changed significantly, in the academy. By the spring conference in 2015, the federal government and its affiliated organizations, such as SSHRC (the latter organization functions, admittedly, at an arm's length), have adopted an explicit policy, of deliberately encouraging the development of knowledge making research activities, and actively promoting dissemination of such research in higher education.

Accordingly, for the Guyanese born poet, and Ottawa, Poet Laureate to be invited to be a major speaker at the Ottawa conference, meant the formal, explicit recognition of Cyril Dabydeen's long term, contributions to the development of Canadian literature. Dr. Lloyd Stanford who is one of the key movers and shakers in the Caribbean community, and prior to retirement, was himself, a highly respected, federal civil servant, invited me to hear Cyril Dabydeen's reading, in the English Department at the University.

This introduction which follows that of Jody Mason's, concentrates on memories of my observations and experiences of listening to, and analyzing Dabydeen's presentation/teaching style, as the evening's readings unfolded.

Memories: I entered the large lecture theatre, and looked around to find Dr. Sanford. He was sitting comfortably, quietly, and very much at home, in the lecture theatre. Specifically, he was sitting at a strategic position, in the middle of the third row of seats, and facing the door. I beamed warmly in greeting. Lloyd, ever the senior statesman, responded. He bowed formally, and smiled.

I sat relatively close to his seat, but a little distance away, in order to be able to absorb the atmosphere of the room. The room gradually became full, as interested academics, entered and settled into their seats around the room. We waited with eager anticipation, at least I did. When Cyril Dabydeen walked into the room with his stack of books and papers. I immediately thought, a well-prepared Keynote speaker/teacher. 
With a nod, Cyril Dabydeen acknowledged the audience, and systematically laid out his books and papers, across the front row. When he was satisfied that the audience was quiet enough, he looked up at the audience, smiled, a warm Caribbean smile, and welcomed everyone for coming to his presentation, on a Sunday afternoon. Dabydeen then, acknowledged with sincere wishes, several of the academics whom he knew, including Dr. Stanford. From Dabydeen's entrance, (in reality, it represented the first part of his presentation), to his manner of laying out the resources/materials, to his welcoming of the audience, everything was accomplished in a formal yet, relaxed manner.

Without hesitation, Cyril Dabydeen, now, became quite business-like. He introduced his readings by mapping the evolution and the context of his work, in precise tones. I smiled quietly, thinking to myself, that the audience (predominantly, Euro-Canadian) would have a very good grasp of the poetry to follow. Yet another excellent academic teaching technique.

Dabydeen began his reading from the pages of selected works that he had earmarked carefully. This allowed the presentation to flow, and unfold smoothly, namely, from reading, to explanation and analysis. Throughout this part of his presentation, Dabydeen communicated effectively, verbally and non verbally. For example, he varied the pace of his delivery, used humour, made eye contact with individual members of the audience, and as importantly, used his voice and body language to present the nuances and implicit meanings in his writings.

As the afternoon's readings unfolded, I remember thinking that I was seeing and hearing a master teacher at work. At the end of his oral presentation, Dabydeen welcomed questions from the responsive audience. Part three of the presentation began with some very probing questions. Cyril Dabydeen, responded. He fielded the questions like an expert cricketer from the West Indies, during its glory days of beating the English teams at their own game.

To conclude my introduction, I return to Judith Hamilton's poem. She continues: ...an get pan mi toe tip/an pin dem [the words] gainst/de sky an see/ef dem can stan up/ when i move/ weh... (1)

Cyril Dabydeen's poems, undoubtedly, stand up in the sky for a long time, even when he walks away. His latest work, titled "Myth-Making: From Margin to Centre", demonstrates his enduring creativity and ability to use words as a mirror to be held up to society and our role in it.

Endnote and Reference:

(1). Translation for readers not familiar with Creole, “... having to turn the words round and round... and rise to the tips of my toes, and pin[them] against the sky, in order to see, if they can stand up by themselves when I move away..." See too, CBC radio interview between Shelia Rogers and Pamela Mordecai, winter 2016, online.

Extracts are from verses six and seven, of Judith Hamilton, (1987,p. 99) "Poem Teacha". In Pamela Mordecai (Editor), "From Our Yard: Jamaican Poetry Since Independence". Kingston: Institute of Jamaica. 